\title{
Prior seed treatment of irrigated rice seeds under laboratory conditions favors expression of physiological potential
}

\author{
A desinfestação prévia de sementes de arroz irrigado em condições laboratoriais favorece a \\ expressão do potencial fisiológico
}

\author{
Bruno Tabarelli Scheidt*, Jaquelini Garcia, Ricardo Trezzi Casa, Cileide Maria Medeiros Coelho, \\ Juliano Berghetti
}

Universidade do Estado de Santa Catarina, Lages, SC, Brasil. * Author for correspondence: brunotabarelli.s@hotmail.com.

Submission: 16/05/2020 / Acceptance: 02/07/2020

\begin{abstract}
The purpose of this study was to analyze prior seed treatment of irrigated rice seeds with sodium hypochlorite and its effect on physiological quality. The experiment was conducted in the seed analysis laboratory of Santa Catarina State University (UDESC). Twenty-four (four per cultivar) seed lots of the cultivars SCSBRS Tio Taka, Epagri 109, SCS116 Satoru, SCS118 Marquês, SCS121 CL, and SCS122 Miura, produced in the Upper Itajaí Valley in the 2016/2017 season, were used in a completely randomized experimental design with four replications. Germination and vigor tests were performed for treated and untreated seeds. For the germination test with treated seeds, there was a higher percentage of normal seedlings and a smaller number of abnormal seedlings and dead seeds. There was significant decrease in vigor without prior seed treatment. The fungi that infested the seeds caused an increase in the percentage of abnormal seedlings and dead seeds. Seed treatment prior to physiological testing positively affects the results regarding the physiological quality of rice seeds.
\end{abstract}

KEYWORDS: Oryza sativa, germination, vigor, sodium hypochlorite, fungi.

\section{RESUMO}

O objetivo deste estudo foi avaliar o efeito da desinfestação prévia de sementes de arroz irrigado com hipoclorito de sódio na qualidade fisiológica. O estudo foi realizado no laboratório de análise de sementes da Universidade do Estado de Santa Catarina (UDESC). Foram utilizados 24 lotes (quatro por cultivar) de sementes dos cultivares SCSBRS Tio Taka, Epagri 109, SCS116 Satoru, SCS118 Marquês, SCS121 CL e SCS122 Miura, produzidas na região do Alto Vale do Itajaí na safra 2016/17. O delineamento experimental utilizado foi o inteiramente casualizado com quatro repetições. Testes fisiológicos de germinação e vigor foram realizados em sementes com e sem desinfestação. Para o teste de germinação com sementes desinfestadas, houve maior porcentagem de mudas normais e menor número de plântulas anormais e sementes mortas. O vigor teve uma redução significativa quando não efetuado a desinfestação prévia das sementes. Os fungos que infestaram as sementes causaram um aumento na porcentagem de plântulas anormais e sementes mortas. $\mathrm{O}$ uso da técnica de desinfestação de sementes antes da submissão a testes fisiológicos, afeta positivamente o resultado da qualidade fisiológica das sementes de arroz.

PALAVRAS-CHAVE: Oryza sativa, germinação, vigor, hipoclorito de sódio, fungos.

The seed is one of the most important means of transporting phytopathogens (JULIATTI et al. 2011). Pathogens may be infesting or infecting the seed. In infestation, fungus is found on the outer surface, whereas in infection, fungus lodges in the inner tissues of the seeds (endosperm and embryonic axis) (BEDENDO 1997).

Currently, marketing of rice seeds in Brazil requires a minimum percentage of $80 \%$ germination (BRASIL 2013). Seeking to meet commercialization standards, companies have adopted physiological tests, such as the germination and vigor tests, as a measure for seed quality control. However, these laboratory tests should be sufficiently rigorous to enable the seed to express its physiological performance.

In the rice crop, there are other factors besides dormancy that may underestimate the physiological 
quality of the seed, such as the presence of pathogenic microorganisms (MIURA 2002). According to RIBEIRO (1996), the presence of certain pathogens in seeds may have direct effects on physiological quality. Because these tests are conducted under optimal conditions for both seed development and pathogens, seed lots are often downgraded because they do not reach the minimum germination rates for commercialization.

However, many of the seed's pathogens which manifest in physiological laboratory tests and affect germination will not be present in the same conditions in the field and may not harm emergence, thereby underestimating the results for seeds tested only in the laboratory and compromising their commercialization. Therefore, it is important to adopt seed analysis laboratory techniques that can minimize the factors that compromise seed performance.

Accordingly, the aim of this study was to evaluate prior seed treatment of rice seeds with sodium hypochlorite and its effect on physiological quality.

This experiment was conducted in the seed analysis laboratory (SAL) of the Veterinary College of Santa Catarina State University (CAV/UDESC) in Lages, Santa Catarina, Brazil. Twenty-four seeds lots of the cultivars SCSBRS Tio Taka, Epagri 109, SCS116 Satoru, SCS118 Marquês, SCS121 CL, and SCS122 Miura, produced in the Upper Itajaí Valley in the 2016/2017 season and supplied by the CRAVIL cooperative, were used in a completely randomized experimental design. Germination and vigor tests were performed on treated and untreated seeds.

The germination test was performed with four replications of 100 seeds. The seeds were spread on three sheets of germitest paper moistened with distilled water at three times the weight of the dry paper. The sheets were then rolled up, stored in plastic bags, and placed in a Mangelsdorf germination chamber at $25 \pm$ $2{ }^{\circ} \mathrm{C}$ for 14 days. The seeds were counted after 7 and 14 days (DAS) (BRASIL 2009).

The accelerated aging test was conducted with four replications of 100 seeds. After dormancy was broken, the seeds were arranged on a stainless steel grid over $40 \mathrm{~mL}^{-1}$ of distilled water inside germination boxes (gerbox) (KRZYZANOWSKI et al. 1991) and placed in an accelerated aging chamber at $41^{\circ} \mathrm{C}$ for 120 hours (ZUCHI \& BEVILAQUA 2012). Next, the germination test was performed for these seeds, as described above.

For the seed treatment, the seeds were immersed in 1.5\% sodium hypochlorite solution for 3 minutes and then washed with sterile water. This method was performed before the germination test and after the seeds were removed from the accelerated aging chamber in the vigor test. The vigor and germination tests were performed for the control seeds without prior seed treatment with sodium hypochlorite.

Analysis of variance was used to interpret the data, and mean separation was determined by Tukey's test $(p<0.05)$ using the $R$ software (R CORE TEAM 2019).

In the germination test, the treated seeds presented a higher percentage of normal seedlings (germination) and a smaller number of abnormal seedlings and dead seeds (Table 1). Conversely, the untreated seeds demonstrated a higher percentage of abnormal seedlings and dead seeds in the germination test. When analyzing forest seeds, NETTO \& FAIAD (1995) found that fungi can cause deterioration, lesions, and seedling abnormalities, making it difficult to analyze the germination test.

Table 1. Percentage (\%) of germination, abnormal seedlings, and dead seeds at the end of the germination test with treated and untreated rice seeds.

\begin{tabular}{lccc}
\cline { 2 - 4 } Disinfestation & \multicolumn{3}{c}{ Germination test } \\
\cline { 2 - 4 } With & Normal & Abnormal & Dead \\
Without & $93 \mathrm{a}^{1}$ & $4 \mathrm{~b}$ & $3 \mathrm{~b}$ \\
\hline Average & $87 \mathrm{~b}$ & $6 \mathrm{a}$ & $7 \mathrm{a}$ \\
\hline CV $(\%)$ & 90 & 5 & 5 \\
\hline
\end{tabular}

${ }^{1}$ Means followed by the same letter in the column do not differ statistically from each other by the Tukey test at $5 \%$ probability.

Although the germination percentage was greater than $80 \%$ in both conditions (with and without prior seed treatment) and in compliance with the minimum requirements for rice seed commercialization, it is important to note that there was a significant difference. Therefore, failure to perform seed treatment prior to 
physiological testing may impair the final germination test results.

Along with the germination test, the seeds were also tested for vigor in the accelerated aging test. A significant loss in vigor was observed without prior seed treatment. The pathogens infesting the seeds caused an increase in the percentage of abnormal seedlings and dead seeds (Table 2). According to SILVA \& SILVA (2000), initial seed contamination by microorganisms and seed water absorption (TEKRONY 1993) may interfere with the interpretation of accelerated aging test results.

Table 2. Percentage (\%) of vigor, abnormal seedlings, and dead seed at the end of the accelerated aging (AA) vigor test with treated and untreated rice seeds.

\begin{tabular}{lccc}
\cline { 2 - 4 } Disinfestation & \multicolumn{3}{c}{ Vigor test } \\
\cline { 2 - 4 } With & Normal & Abnormal & Dead \\
Without & $91 \mathrm{a}^{1}$ & $2 \mathrm{~b}$ & $22 \mathrm{a}$ \\
\hline Average & $73 \mathrm{~b}$ & $5 \mathrm{a}$ & 14 \\
\hline CV $(\%)$ & 82 & 4 & 24.49
\end{tabular}

Means followed by the same letter in the column do not differ statistically from each other by the Tukey test at $5 \%$ probability.

BEVILACQUA et al. (2011) also observed the efficiency in using sodium hypochlorite to reduce microbial contamination (fungal and bacterial) in order to optimize physiological quality.

The vigor test adopted in the study involves high temperatures and humidity, which may favor the attack of microorganisms (HENNIPMAN et al. 2017). The fungi Alternaria padwickii (Ganguly), Bipolaris oryzae (Breda de Haan), Cercospora janseana (Racib.), Fusarium moniliforme (Sheldon), Microdochium oryzae (Hashioka \& Yokogi), Pyricularia oryzae (Cav.), and Sarocladium oryzae (Saw) are some of the main pathogens associated with rice seeds (MEW \& GONZALES 2002, SOSBAI 2018). Some of them are referred to as contaminating or opportunistic fungi, such as Aspergillus sp., Penicillium sp., and Rhizopus $\mathrm{sp}$., and others, which may reduce germination and vigor percentages. Fungal contamination by Aspergillus spp. and Rhizopus spp. limited the estimation and influenced peanut seed deterioration during vigor testing (ROSSETTO et al. 2003).

FERRAZ \& CALVIN (2010) also claim that the presence of fungi can hamper assessments of a seed sample's physiological potential.

In conclusion, seed treatment with sodium hypochlorite prior to physiological testing positively affects the physiological quality of rice seeds.

\section{ACKNOWLEDGEMENTS}

Coordination for the Improvement of Higher Education Personnel (CAPES), Brazil, code 001.

\section{REFERENCES}

BEDENDO IP. 1997. Doenças do arroz. In: KIMATI H et al. (Ed.). Manual de Fitopatologia. 3.ed. São Paulo: Agronômica Ceres. p.85-99.

BEVILACQUA CB et al. 2011. Desinfestação superficial, germinação e regeneração in vitro a partir de sementes de calêndula. Ciência Rural 41: 761-766.

BRASIL. 2009. Regras para Análise de Sementes. Brasília: MAPA/ACS. 399p.

BRASIL. 2013. Instrução Normativa no 45. Brasília: MAPA.

FERRAZ IDK \& CALVI DP. 2010. Teste de Germinação. In: LIMA JUNIOR MJV. (Ed.). Manual de Procedimentos para Análise de Sementes Florestais. Manaus: UFAM. p.55-110.

HENNIPMAN HS et al. 2017. Qualidade sanitária e fisiológica de sementes de araucária durante armazenamento. Ciência Florestal 27: 643-654.

JULIATTI FC et al. 2011. Qualidade fisiológica e sanitária de sementes de algodoeiro produzidas nas regiões do triângulo mineiro e sul de Goiás. Bioscience Journal 27: 24-31.

KRZYZANOWSKI FC et al. 1991. Relato dos testes de vigor disponíveis para as grandes culturas. Informativo Abrates 1: $15-50$.

MEW TW \& GONZALES P. 2002. A handbook of rice seedborne fungi. Makati City: Science Publishers. 83p.

MIURA L. 2002. Doenças. In: Epagri Arroz irrigado: Sistema pré-germinado. Florianópolis, Epagri. p.203-227.

NETTO DAM \& FAIAD MGR. 1995. Viabilidade e sanidade de sementes de espécies florestais. Revista Brasileira de 
Sementes 17: 75-80.

R CORE TEAM. R. 2019. A language and environment for statistical computing. R Foundation for Statistical Computing. RIBEIRO AS. 1996. Tratamento de sementes com fungicidas. In: LUZ WC. (Ed). Revisão Anual de Patologia de Plantas. Passo Fundo: EMBRAPA. p.381-408.

ROSSETTO CAV et al. 2003. Avaliação da aplicação de fungicida às sementes de amendoim antes do envelhecimento acelerado. Revista Brasileira de Sementes 25: 101-107.

SILVA MAD \& SILVA WR. 2000. Comportamento de fungos e de sementes de feijoeiro durante o teste de envelhecimento artificial. Pesquisa Agropecuária Brasileira 35: 599-608.

TEKRONY DM. 1993. Accelerated aging test. Journal of Seed Technology 7: 573-577.

SOSBAI. 2018. Arroz irrigado: recomendações técnicas da pesquisa para o Sul do Brasil. In: XXXII Reunião Técnica da Cultura do Arroz Irrigado. Farroupilha: Sociedade Sul-Brasileira de Arroz Irrigado. 205p.

ZUCHI J \& BEVILAQUA GAP. 2012. Qualidade fisiológica de sementes de arroz armazenadas em diferentes embalagens e temperaturas. Pelotas: EMBRAPA. 20p. (Boletim de Pesquisa e Desenvolvimento 163). 